\title{
Biological traits and community patterns of Trichoptera at two Patagonian headwater streams affected by volcanic ash deposition
}

\author{
Cecilia Brand ${ }^{*}$ and María Laura Miserendino
}

\begin{abstract}
Background: Sediment deposition constitutes a major disturbance having negative effects on aquatic ecosystems. The Chaitén Volcano eruption occurred on May 2008. As a consequence, broad areas along the Argentine Andes $\left(40^{\circ} \mathrm{S}\right.$ to $\left.46^{\circ} \mathrm{S}\right)$ were covered with ash. This event provided an excellent opportunity to investigate how a natural and exceptional sedimentation episode affects Trichoptera communities.

Results: We assessed changes in caddisfly community attributes (composition, density and diversity) and 11 biological traits, by comparing pre-eruption (May 2007 to April 2008) and post-eruption (July 2008 to March 2010) data at two headwater streams. As a consequence of the event, total suspended solids increased and Trichoptera richness and density significantly diminished. By March 2010, two common species of Hydroptilidae (Metrichia patagonica and Metrichia neotropicalis) were no longer recorded at one site; while species richness and density values were still low indicating that the community had not recovered. Scrapers, shredders, and predators were among the most affected functional feeding groups and changes in their relative abundance were tracked in subsequent years after the ashfall event.
\end{abstract}

Conclusions: In this study, species tolerance to sedimentation was related to certain traits such as poorly synchronized life history, filter-feeding habits, rounded body shape, tegument respiration mode, and poorly sclerotized life forms.

Keywords: Disturbance; Caddisflies; Volcanic ash; Traits; Total suspended solids; Patagonia

\section{Background}

Biological and functional traits are variables describing characters of organisms (including morphological characters with biological implications), either on a continuous scale or through categories or trait-states (Statzner and Bêche 2010). The biological trait profile of a community offers an alternative approach for assessing the response of a stream community to disturbance, and can be expected to reflect the functional relationships between biota and environmental characteristics (Townsend et al. 1997; Dolédec et al. 2011).

Based on Southwood's habitat template model, trait approaches propose that habitat selects for characteristic life history traits through natural selection, and

* Correspondence: cecibrand@hotmail.com

Laboratorio de Investigaciones en Ecología y Sistemática Animal (LIESA),

CIEMEP, CONICET, UNPSJB, Sede Esquel, Sarmiento 849, Esquel 9200, Chubut, Argentina species are expected to respond to environmental gradients (Southwood 1977; Poff et al. 2006; Buendia et al. 2013). In this context, trait patterns can be indicators of the source of impairment, and species possessing relevant adaptive traits are likely to remain (Statzner et al. 2004; Buendia et al. 2013). Therefore, changes in trait profiles reflect changes in the ability of invertebrate communities to cope with disturbances, as only those traits conferring resistance and resilience are selected (Statzner and Bêche 2010; Vandewalle et al. 2010). Facing an environmental disturbance, populations of species with traits conferring resilience or resistance are predicted to increase (Townsend et al. 1997).

Among natural disturbances, explosive volcanic eruptions can exert major changes in the surrounding landscape (Jones and Gislason 2008; Ruggieri et al. 2011). The magnitude and extent of this kind of phenomena as 
well as their ecological consequences vary widely depending on the type of eruption and distance to the volcano (Óskarsson 1980; Annen and Wagner 2003; Witham et al. 2005). Fine volcanic ash deposition is often responsible for the more widespread impact of a volcanic eruption, affecting hundreds of square kilometers $\left(\mathrm{km}^{2}\right)$ by covering the soil with dense layers of volcanic material, leading to significant changes in both terrestrial and aquatic environments (McDowall 1996; Del Moral and Grishin 1999; Martin et al. 2009). While eruptions may be ephemeral, ashfall sediments can remain in the local environment for many years to decades, and in arid conditions, they could be preserved for millions of years (Ruggieri et al. 2011). Additionally, strong wind storms may result in ash resuspension, causing similar effects to those of the original eruption (Inbar et al. 1995; Ruggieri et al. 2011).

The effect of sedimentation processes of volcanic origin on benthic fauna are comparable to those caused by certain anthropogenic activities such as those derived from dredging, land movement, and deforestation (Miserendino et al. 2012). According to Paul and Meyer (2001), a strong decrease in density and diversity of benthic macroinvertebrates can be expected as a response to siltation. Increased turbidity has been associated with higher insect drifts (Doeg and Milledge 1991), and generally, the shift in bed sediments from stable boulder-cobble to finer sediment sizes favors species adapted to unstable habitats, such as chironomids and oligochaetes (Pedersen and Perkins 1986; Collier 1995). Studies of sedimentation processes related to urban streams, have shown a decrease in available refugial space, making invertebrates highly susceptible to drift during floods (Borchardt and Statzner 1990). It has also been confirmed that high levels of suspended solids alter benthic primary production in streams. Wantzen (1998) observed a significant scouring effect by silt ('sand jet effect') that reduced or removed epilithic algae and biofilms, which play a key role as a food source for grazing invertebrates. Additionally, high loads of suspended solids may increase turbidity, reducing stream primary production and interfering predator-prey relationships (e.g., optical orientation of dragonfly larvae). Moreover, allochtonous material, such as leaves and detritus may be covered by slow sand movement and become inaccessible for epibenthic detritivorous animals, consequently modifying the trophic structure (Wantzen 1998, 2006).

Following a natural disturbance like an ashfall phenomenon, the recolonization process will depend on species showing selected traits that maximize their survival rates, arrival of new colonizers, and the presence of resources as well as appropriate habitat for organisms to establish. As shown by Anderson and Wisseman (1987), 5 years after Mt. Saint Helen's eruption, Trichoptera species were still uncommon in benthic samples taken in a stream $15 \mathrm{~km}$ northeast of the mountain. However, light traps showed an unexpected species richness of adult Trichoptera, suggesting that recovery of fauna was not limited by adult colonists, but by changes in the physical environment that prevented larvae from developing appropriately. Dolédec et al. (2011) proposed that after sediment deposition episodes, those species displaying egg protection, being burrowers and/or fine detritus consumers might be favored.

The eruption of Chaitén volcano ( $42^{\circ} 50^{\prime} \mathrm{S} ; 72^{\circ} 39^{\prime} \mathrm{W}$ ) is considered to be the largest one at a global scale since that of the Hudson (Chile) in 1991 (Nillni and Bitschene 1995), and was the first large eruption of high-silica rhyolite since that of Alaska's Novarupta volcano in 1912 (Pallister et al. 2010). On May of 2008, its explosion caused a strong emission of volcanic ashes of predominantly rhyolitic composition, which covered broad areas ranging from 0.1 to $15 \mathrm{~mm}$ of thickness in the Argentine side of the Andes Mountains (Watt et al. 2009). As a result of the prevailing western winds, the lighter material was transported eastward in a few hours, affecting broad areas of northwestern Chubut province (Argentina), between $42^{\circ} \mathrm{S}$ and $46^{\circ} \mathrm{S}$ (Ovdas 2008).

Despite that many studies having attempted to describe the effects of volcanic ash deposition on aquatic environments, few of them support their comparisons with pre-eruption data (Anderson 1992; Antos and Zobel 2005). During 2007 to 2008, we were conducting a research on the life history of Trichoptera species inhabiting Nant y Fall and Chiquito Streams when the eruption of the Chaitén volcano occurred (May 2008). This provided a unique opportunity to investigate how a natural and exceptional (i.e., non-cyclic) episode affected the Trichoptera community in terms of structure, species richness, and biological traits. We hypothesize that traits conferring resistance to sediment deposition effects might be related to greater mobility or good swimming abilities, preference for depositional habitats and poorly synchronized life cycles.

In this study, we attempt to 1) assess the changes in attributes of the Trichoptera community in two streams affected by heavy ash deposition, 2) evaluate the persistence of these changes, and 3) discuss which biological and functional traits improved the survival chances of caddisfly species.

\section{Methods}

\section{Study site}

The study was undertaken in a transitional mountain and piedemont area, with a marked altitudinal gradient, located in the ecotone between the Sub-antarctic Forests and Patagonian Steppe (Paruelo et al. 1998) of northwestern Chubut province (Argentina).

The samples were taken from two streams (Nant y Fall and Chiquito), on the Argentine side of the Andes 
Mountains. Ashfall at both sites was comprised between 5 and $10 \mathrm{~mm}$ (total catchment average) (Watt et al. 2009) (Figure 1). However, values observed in the margins were between 15 and $25 \mathrm{~mm}$.

Nant y Fall Stream (71 $25^{\prime} 17^{\prime \prime} \mathrm{W} ; 43^{\circ} 13^{\prime} 24^{\prime \prime}$ S; 690 meters above sea level (m.a.s.l.); Futaleufú-Yelcho basin), is a third-order stream located downstream a small lake (Rosario Lake), and drains a catchment of $162 \mathrm{~km}^{2}$. Chiquito Stream ( $71^{\circ} 30^{\prime} 22^{\prime \prime} \mathrm{W}$; $43^{\circ} 21^{\prime} 43^{\prime \prime}$ S; 670 m.a.s.l.) is a permanent second-order stream in the Río Frío basin, draining a small catchment of $11 \mathrm{~km}^{2}$ (Figure 1).

Rainfall in the area, as estimated from a study by Jobbágy et al. (1995), is $600 \mathrm{~mm} /$ year. The discharge pattern is bimodal, with peaks concurrently with winter rainfalls, where $46 \%$ of the annual precipitation occurs (Paruelo et al. 1998), and in spring with snowmelt (Coronato and del Valle 1988).

At both sites, riparian forest is composed by the deciduous tree Nire (Nothofagus antarctica), several native shrub species (e.g., Schinus patagonicus, Berberis buxifolia, and Berberis heterophylla) (León et al. 1998), while $60 \%$ to $70 \%$ of the total coverage consists of herbaceous species. At both catchments, main agricultural activities are cattle grazing and forest practices such as wood extraction, no change in land use practices or intensity was recorded during any of the visits to the sites.

Aquatic vegetation covers one quarter of the studied reach at Nant y Fall and is mainly represented by the submersed Isoetes savatieri, Myriophyllum quitense, Limosella australis, Ranunculus flagelliformis, Callitriche lechleri, and Lilaeopsis macloviana; and the emergent macrophytes Mimulus glabratus, Verónica anagallis-aquatica, Eleocharis albibracteata, Juncus burkartii, Juncus diemii and Juncus microcephalus. At Chiquito Stream, bryophytes cover $50 \%$ to $80 \%$ of the reach.

\section{Environmental characterization and sampling procedure}

Both sites were sampled monthly during the year previous to the eruption of Chaitén volcano (from May 2007 to April 2008) and were revisited after the episode on six occasions (June and October 2008; February, June, and October 2009; and March 2010). This sequence of the post-eruption sampling was coordinated with another regional survey that involved several aquatic environments in the area (Miserendino et al. 2012).

Substrate size composition was estimated as percentage of boulder $(>25 \mathrm{~cm})$, cobble $(6.4$ to $25 \mathrm{~cm})$, pebble $(1.6$ to $6.4 \mathrm{~cm})$, gravel $(2$ to $16 \mathrm{~mm})$, and sand $(0.25$ to $2 \mathrm{~mm}$ ) in the reach, using a $1-\mathrm{m}^{2}$ grid (Ward 1992). At post-eruption dates, an assessment of ash deposition was performed at each stream, depth of the stream bank ash deposits were measured with a caliper (mm). Additionally, percentage of riverbed covered by ash was estimated visually for riffles and pools separately.

Average depth $(\mathrm{cm})$ was calculated from five measurements on three transects across the channel with a calibrated stick; wet width $(\mathrm{m})$ was also measured. Current speed $(\mathrm{m} / \mathrm{s})$ was estimated in mid-channel by timing a

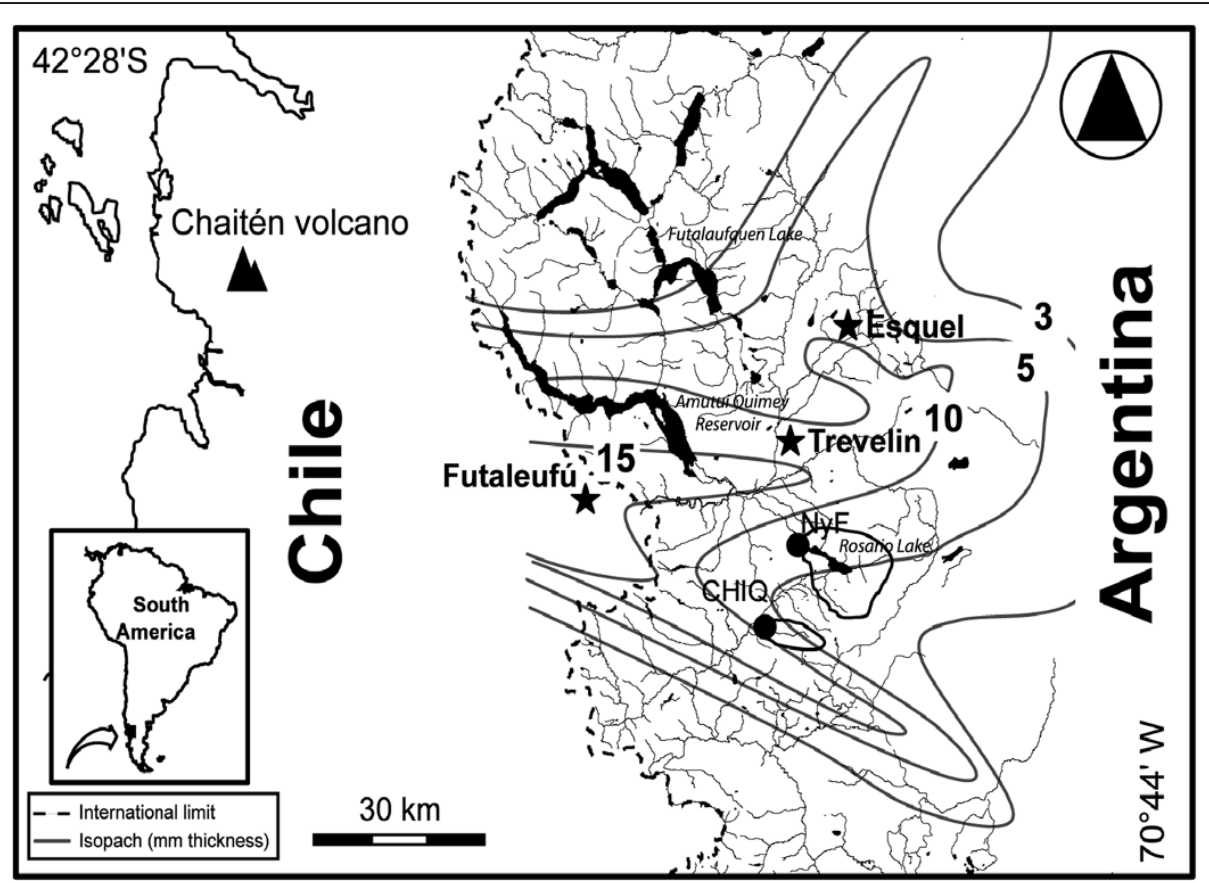

Figure 1 Map of the study area. Shows location of the two sampling sites, Nant y Fall and Chiquito (filled circles), volcano and main Argentine cities (stars), Isopachs (black contours) represents ash thickness in mm. Reproduced and adapted from Watt et al. (2009) (Patagonia, Argentina). 
float (average of three trials) as it moved over a distance of $10 \mathrm{~m}$ (Gordon et al. 2004). Discharge $\left(\mathrm{m}^{3} / \mathrm{s}\right)$ was obtained by combining depth, wet width, and current speed as in the study by Gordon et al. (2004). On each sampling occasion, water temperature, $\mathrm{pH}$, specific conductance $\left(\mu \mathrm{S}_{20} / \mathrm{cm}\right)$ and dissolved oxygen $(\mathrm{mg} \mathrm{O} / 2)$ were measured with a multi-parameter probe (Hach SensION 156, Hach, Loveland, CO, USA).

Total suspended solids (TSS) were measured gravimetrically from separate water samples (2,000-ml plastic bottles) taken from the mid channel. In the laboratory, differences between the final and initial weights of dried filters were obtained (APHA 1999). Since no TSS data were taken during pre-eruption dates, data obtained in a previous study at the same sampling sites (2005 to 2006 period, Miserendino et al. 2012) were used to compare with post-eruption values. Since none of the sites revisited experienced major changes in land-use practices before and after the ashfall event, we assumed that TSS variation was exclusively related to the volcanic episode.

\section{Caddisfly sampling}

At each site and at all dates (pre-eruption: $n=12$, posteruption $n=6)$, larvae were collected from three riffles using a Surber net $\left(0.09 \mathrm{~m}^{2} ; 250-\mu \mathrm{m}\right.$ mesh size $)$. Samples $(n=108)$ were fixed with formaldehyde, in the field.

Larvae were sorted manually under $\times 5$ magnification, counted and preserved in $70 \%$ alcohol. Caddisfly larvae were identified to the lowest possible taxonomic level using available keys (Angrisano 1997; Sganga and Fontanarrosa 2006; Angrisano and Sganga 2009). Taxa were assigned to functional feeding groups based upon knowledge of feeding modes (mouthpart morphology and behavior), by gut content analysis and using available references (Merritt et al. 2008; Miserendino and Masi 2010; Brand and Miserendino 2011a, b, 2012).

Caddisfly community data were analyzed through the following attributes: species/taxa richness, density (ind $/ \mathrm{m}^{2}$ ), Shannon diversity index $\left(\mathrm{H}^{\prime}\right)$, and density and relative abundance of trophic guilds (Merritt et al. 2008).

\section{Caddisfly trait data}

Information on 11 traits related to life history, morphology, and ecology was obtained for all caddisfly species (27 species). Traits included in the life history category were duration ( $<10$ months and $>10$ months) and synchronicity (poorly synchronized and well synchronized) of the life cycle (Poff et al. 2006; Brand and Miserendino 2011a, 2012). Morphological traits include a spectrum of five larval attributes concerning: attachment (free living, non-attached forms vs. sedentary or attached forms), armoring (three states, ranging from non or poorly sclerotized larvae, heavily sclerotized larvae and larvae that construct cases out of mineral or inorganic material), body shape (fusiform and non-fusiform), body size (ranges: small $<9 \mathrm{~mm}$; medium 9 to $16 \mathrm{~mm}$; and large $>16 \mathrm{~mm}$ ) and respiration modes (tegumentary and gills) (Poff et al. 2006). Ecological larval traits included information related to hydraulic condition preferences (exclusively depositional, depositional and erosional, and erosional only), substratum and habitat selectivity (coarse, gravel, sand, macrophyte and organic detritus litter), food preferences (detritus, plant detritus, living macrophytes, living microphytes, and living macroinvertebrates), and feeding behavior (deposit feeder, shredder, scraper, filter-feeder, piercer, predator) (Poff et al. 2006; Brand and Miserendino 2011a, b; Dolédec et al. 2011; Brand et al. 2012). Only traits with information available for all species were selected; and trait assignment was performed using regional databases and available publications (Brand and Miserendino 2011a; Brand and Miserendino 2011b; Brand and Miserendino 2012; Brand et al. 2012). Species trait information was then rescaled according to the number of states (from 1 to $x$, with $x$ being the total number of states in each trait). Values then, were rescaled so that the sum of all states equalled one. This information was used to build the species-traits matrix for each stream.

\section{Statistical procedure}

One-way ANOVA model was employed in order to detect significant differences between pre- and post-eruption values of physicochemical variables. Prior to analyses variables were $\log (x+1)$ transformed. Student's $t$ test for dependent samples comparisons were used in order to identify the main changes between pre- and post-eruption dates in the caddisfly community attributes. Significant differences in species richness, total density, Shannon diversity, and the main density of functional feeding groups were assessed (Sokal and Rohlf 1995).

Principal Component Analyses (PCA) was used to determine patterns of functional trait composition in the caddisfly assemblage at each stream. This ordination method (linear model) provided information enabling a more detailed examination of the relationship between the biologically defined traits at pre- and post-eruption dates. A matrix of the relative prevalence of each trait state (within each of the 11 traits) on each sampling occasion at both sites $(n=36)$ was created by log-transformed abundance weighting the taxon scores for each trait state for a given sample. The sums of weighted scores (one per trait state) were then expressed as the relative abundance distribution (within a trait), giving the sample trait profile (Larsen and Ormerod 2010; Feio and Dolédec 2012). The final matrix employed in the ordination (Sampling dates $\times$ Traits states) was obtained by adding the values of the trait states at each month. Ordinations were performed using CANOCO package version 4.0 (ter Braak and Smilauer 1998). 


\section{Results}

\section{Physicochemical variables}

Substrate size composition at Nant y Fall site was dominated by gravel (30\%), cobbles $(25 \%)$, and boulders (20\%), and the remaining $25 \%$ was distributed among smaller fractions; Chiquito Stream dominant fractions were cobbles $(30 \%)$, pebbles $(25 \%)$, and boulders $(15 \%)$, with the remaining 30\% distributed among smaller fractions. Post-eruption substrate characterization did not vary from that of pre-eruption.

Immediately after the first eruption, ash deposition at the margins of Chiquito sampling site averaged $20 \mathrm{~mm}$ deep. Moreover, substrate occurring within a riffle were $50 \%$ covered in ash, while at deposition areas, up to $70 \%$ was covered with ash. At Nant y Fall site, ash deposition at the margins averaged $17.5 \mathrm{~mm}$ deep, while riffles and pools presented a $15 \%$ and $80 \%$ of the substrate covered with ash, respectively. During the study period ash deposit remained in the river banks, pool coverage decreased to $10 \%$, and riffles presented no evidence of ash deposition.

The environmental characterization of study sites at pre- and post-eruption dates is shown in Table 1. Water temperature, wet and dry channel widths, depth, current velocity, and discharge showed no significant changes when comparing pre- and post-eruption datasets. Conductivity values were between 72.3 and $119.4 \mu \mathrm{S} / \mathrm{cm}$ (Nant y Fall), and 29.4 and $104.7 \mu \mathrm{S} / \mathrm{cm}$ (Chiquito). However, mean values did not significantly increase after the eruption. Dissolved oxygen ranged from 6.6 to $15.4 \mathrm{mg} / \mathrm{l}$, with the highest mean values on post-eruption dates at both sites. Post-eruption $\mathrm{pH}$ values were comparable to preeruption values.

Mean values of TSS were significantly higher on posteruption dates at the two study sites (ANOVA $p<0.05$ ) (Table 1), and reflected ash deposition and remobilization episodes. Post-eruption values at Nant y Fall Stream (between 7 and $13.5 \mathrm{mg} / \mathrm{l}$ ) were four times higher than before the eruption (1.7 to $3.6 \mathrm{mg} / \mathrm{l})$ while at Chiquito Stream, post-eruption values (between 1.3 and $24.1 \mathrm{mg} / \mathrm{l}$ ) were about three times higher than pre-eruption ones (between 2 to $6.1 \mathrm{mg} / \mathrm{l})$.

\section{Community composition}

Nant y Fall community attributes changed after the ashfall episode. Cumulative species richness on pre-eruption dates (16 species from 8 families), decreased on posteruption samples (12 species from 6 families) (Table 2, Figure 2). Mean species richness decrease significantly in post-eruption samples, from 8 to 6 species (Table 3, Figure 2). Caddisfly density was also lower at post-eruption dates; however, these values were not significantly different from those recorded before the eruption (Tables 2 and 3, Figure 2). At this site, two caddisfly species accounted for more than $90 \%$ of the abundance during pre- and post-eruption surveys; Parasericostoma ovale (Sericostomatidae), with a density of 3,916 and 2,072 ind $/ \mathrm{m}^{2}$ and Smicridea frequens (Hydropsychidae), with a density of 1,187 and $1,751 \mathrm{ind} / \mathrm{m}^{2}$, respectively. In contrast, Shannon diversity increased significantly posteruption (Tables 2 and 3). This was probably explained by a drop in density of the dominant $P$. ovale, representing a decrease of about $20 \%$ in its relative contribution to the total density.

Caddisfly community composition at Chiquito Stream also changed after the volcanic eruption (Figure 2, Table 2). Cumulative species richness values were comparable between pre- and post-eruption periods (17 species in 9 families, Table 2). However, mean species richness (from 8 to 5 species), density ( 984 to 204 ind $/ \mathrm{m}^{2}$ ), and diversity (from 1.5 to 1.2 ) all significantly declined after the eruption (Tables 2 and 3, Figure 2). Relative abundance of

Table 1 Mean values and range of physicochemical variables at the two studied sites (Northwestern Patagonia Argentina)

\begin{tabular}{|c|c|c|c|c|}
\hline & \multicolumn{2}{|c|}{ Nanty Fall } & \multicolumn{2}{|c|}{ Chiquito } \\
\hline & Pre-eruption & Post-eruption & Pre-eruption & Post-eruption \\
\hline Water temperature $\left({ }^{\circ} \mathrm{C}\right)$ & 11.6 (3.9 to 22.5$)$ & 12.6 (5.3 to 20.8$)$ & $8(2.4$ to 13.1$)$ & 7.6 (2.7 to 12.6$)$ \\
\hline Channel wetted width (m) & 17.1 (14 to 22.7 ) & 22 (18.2 to 27$)$ & 2.7 (2 to 3.1$)$ & $2.2(1.5$ to 2.5$)$ \\
\hline Channel dry width (m) & 31.5 & 31.5 & 3.5 & 3.5 \\
\hline Depth $(\mathrm{cm})$ & 20.9 (15.6 to 32.6) & 29 (19.5 to 38.4) & 12.7 (9 to 20 ) & $12.4(7.9$ to 17.7$)$ \\
\hline Current velocity (m/seg) & 0.7 (0.5 to 1.16$)$ & 0.7 (0.5 to 0.8$)$ & 0.7 (0.4 to 1.18$)$ & $1(0.6$ to 1.6$)$ \\
\hline Discharge $\left(\mathrm{m}^{3} / \mathrm{seg}\right)$ & $3.2(1.31$ to 7.21$)$ & 4.1 (2.31 to 4.7$)$ & $0.2(0.1$ to 0.6$)$ & $0.3(0.1$ to 0.5$)$ \\
\hline Conductivity ( $\mu \mathrm{S} / \mathrm{cm})$ & 89.7 (72.3 to 119.4$)$ & 94.6 (76.3 to 107.8$)$ & $52(29.4$ to 104.7$)$ & $55.3(42.8$ to 73.2$)$ \\
\hline Dissolved oxygen (mg/l) & 9.7 (7.06 to 13.23$)$ & 10.5 (7.7 to 12.7$)$ & $7.2(7.2$ to 15.4$)$ & 10.3 (6.6 to 13.7$)$ \\
\hline $\mathrm{pH}$ & $7.6(6.5$ to 8.5$)$ & 7.6 (6.4 to 8.6$)$ & $7.3(6.8$ to 8$)$ & $7.3(6.2$ to 8.1$)$ \\
\hline Total suspended solids (mg/l) & $2.7(1.7 \text { to } 3.6)^{a}$ & $10.25(7$ to 13.5$)$ & $4(2 \text { to } 6.1)^{a}$ & $12.8(1.3$ to 24.1$)$ \\
\hline
\end{tabular}

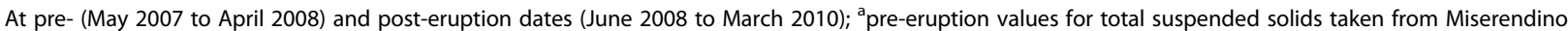
et al. (2012). 
Table 2 Mean density (ind $/ \mathrm{m}^{2}$ ), range, and functional feeding groups of the 27 caddisfly taxa

\begin{tabular}{|c|c|c|c|c|c|}
\hline & \multirow[t]{2}{*}{ FFG } & \multicolumn{2}{|c|}{ Nant y Fall } & \multicolumn{2}{|c|}{ Chiquito } \\
\hline & & Pre-eruption & Post-eruption & Pre-eruption & Post-eruption \\
\hline \multicolumn{6}{|l|}{ Glossosomatidae } \\
\hline Mastigoptila longicornuta (Schmid 1958) & Scr & 51 (0 to 388) & 33 (0 to 137$)$ & & \\
\hline Scotiotrichia ocreata (Mosely 1934) & Scr & & & $248(0$ to 488$)$ & 20 (0 to 89$)$ \\
\hline \multicolumn{6}{|l|}{ Helicophidae } \\
\hline Austrocentrus valgiformis Flint 1997 & Scr & & & $18(0$ to 44$)$ & 7 (0 to 15$)$ \\
\hline Eosericostoma aequispina Schmid 1955 & Scr & & & 61 (4 to 207) & $2(0$ to 15$)$ \\
\hline \multicolumn{6}{|l|}{ Hydrobiosidae } \\
\hline Cailloma pumida Ross 1956 & $P$ & $1(0$ to 7$)$ & $1(0$ to 4$)$ & $6(0$ to 33$)$ & $1(0$ to 4$)$ \\
\hline Metachorema griseum Schmid 1957 & P & & $11(0$ to 30$)$ & & \\
\hline Neoatopsyche brevispina Schmid 1957 & $P$ & $47(0-163)$ & 52 (0 to 178$)$ & 50 (7 to 129$)$ & 23 (15 to 33) \\
\hline Neoatopsyche unispina Flint 1967 & $P$ & $20(0$ to 55$)$ & 10 (0 to 41$)$ & $1(0$ to 7$)$ & $1(0$ to 4$)$ \\
\hline Neopsilochorema tricarinatum Schmid 1955 & $P$ & 28 (0 to 85$)$ & 23 (4 to 33 ) & $3(0$ to 7$)$ & $1(0$ to 7$)$ \\
\hline Rheochorema lobuliferum Flint 1967 & $P$ & $2(0$ to 11$)$ & & & \\
\hline Rheochorema robustum Schmid 1955 & $P$ & & & $3(0$ to 11$)$ & $2(0$ to 7$)$ \\
\hline Rheochorema tenuispinum Schmid 1955 & $P$ & & & 8 (0 to 18$)$ & $4(0$ to 7$)$ \\
\hline \multicolumn{6}{|l|}{ Hydropsychidae } \\
\hline Smicridea annulicornis (Blanchard 1851) & CF & 135 (7 to 703$)$ & 108 (15 to 259$)$ & $64(0$ to 429$)$ & 11 (4 to 30$)$ \\
\hline Smicridea frequens (Navás 1930) & CF & $1,187$ (48 to 4,755$)$ & $1,751(163$ to 4,518$)$ & $6(0$ to 19$)$ & \\
\hline \multicolumn{6}{|l|}{ Hydroptilidae } \\
\hline Oxyethira bidentata Mosely 1934 & $\mathrm{AP}$ & $3(0$ to 30$)$ & $2(0$ to 7$)$ & & \\
\hline Hydroptilidae sp. A & Scr & $2(0$ to 15$)$ & 2 (0 to 15$)$ & & \\
\hline Metrichia patagonica (Flint 1983) & Scr & & & $22(4$ to 59$)$ & \\
\hline Metrichia neotropicalis Schmid 1958 & Scr & & & 13 (0 to 63) & \\
\hline \multicolumn{6}{|l|}{ Leptoceridae } \\
\hline Brachysetodes quadrifidus Schmid 1955 & $\mathrm{SH}$ & 155 (18 to 396$)$ & 27 (0 to 55$)$ & 139 (18 to 314$)$ & 17 (0 to 67$)$ \\
\hline Hudsonema flaminii (Navás 1936) & $\mathrm{SH}$ & $2(0$ to 7$)$ & & & $1(0$ to 4$)$ \\
\hline \multicolumn{6}{|l|}{ Limnephilidae } \\
\hline Monocosmoecus sp. & $\mathrm{SH}$ & 10 (0 to 52$)$ & & 5 (0 to 18$)$ & 4 (0 to 18$)$ \\
\hline Verger sp. & $\mathrm{SH}$ & 11 (0 to 67) & & & \\
\hline \multicolumn{6}{|l|}{ Philorheithridae } \\
\hline Psilopsyche molinai Navás 1926 & $P$ & $2(0$ to 7$)$ & & $6(0$ to 22$)$ & $1(0$ to 4$)$ \\
\hline \multicolumn{6}{|l|}{ Polycentropodidae } \\
\hline Polycentropus sp. & $P$ & & & & $1(0$ to 4$)$ \\
\hline \multicolumn{6}{|l|}{ Sericostomatidae } \\
\hline Myotrichia murina Schmid 1955 & $\mathrm{SH}$ & & & 329 (22 to 858$)$ & 102 (30 to 226$)$ \\
\hline Parasericostoma cristatum Flint 1983 & $\mathrm{SH}$ & & & & 7 (0 to 26) \\
\hline Parasericostoma ovale (Schmid 1955) & $\mathrm{SH}$ & $3,916(2,546$ to 8,688$)$ & $2,072$ (674 to 4,177$)$ & & \\
\hline Richness & & 8 (6 to 10$)$ & $6(4$ to 8$)$ & 8 (5 to 10$)$ & 5 (2 to 8$)$ \\
\hline Density & & $5,573(3,015$ to 14,230$)$ & $4,094(1,140$ to 8,998$)$ & $984(196$ to 2,012$)$ & 204 (67 to 377) \\
\hline Shannon diversity & & $0.78(0.6$ to 1$)$ & $1(0.8$ to 1.3$)$ & $1.5(1.2$ to 1.7$)$ & $1.2(1$ to 1.4$)$ \\
\hline
\end{tabular}

Recorded at pre and post-eruption dates for Nant y Fall and Chiquito Streams (Patagonia, Argentina). Mean values and range of the total density, species richness, and Shannon diversity are summarized for both study periods; Scr, scraper; P, predator; CF, collector-filterer; AP, algal piercer; SH, shredder. 

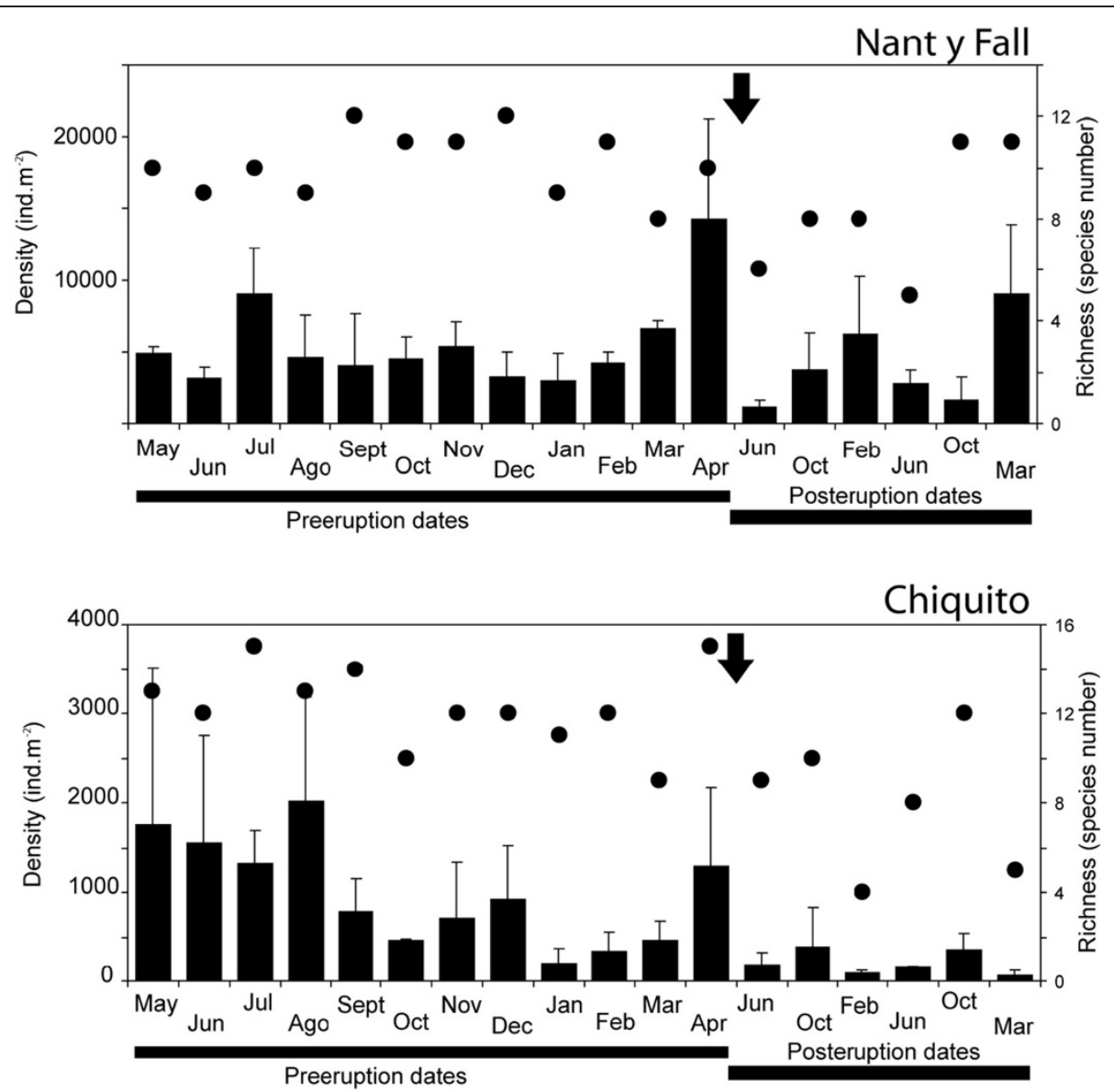

Figure 2 Mean caddisfly density (bars, +SD) and species richness (dots). At pre (May 2007 to Apr 2008) and post-eruption (Jun 2008 to Mar2010) dates, at Nant y Fall and Chiquito Streams (Patagonia, Argentina).

species changed considerably (Table 2). The dominant species at this site were Myotrichia murina (Sericostomatidae) and Scotiotrichia ocreata (Glossosomatidae); however, both species density showed a post-eruption decline. Neoatopsyche brevispina (Hydrobiosidae) also decreased by $50 \%$ in abundance after the eruption (Table 2 ).

\section{Functional feeding groups}

At Nant y Fall Stream, only shredder density significantly decreased after the volcano eruption $(t$ test $p<0.05$, Table 3). No significant differences were observed for the other groups. Collector-filterers' relative proportion increased in years following the eruption and this was

Table 3 Results of student's $\boldsymbol{t}$ test for dependent samples

\begin{tabular}{|c|c|c|c|c|}
\hline & \multicolumn{2}{|c|}{ Nant y Fall } & \multicolumn{2}{|c|}{ Chiquito } \\
\hline & $t_{(1.52)}$ & Observed relationship & $t_{(1.52)}$ & Observed relationship \\
\hline Species richness & $4.1^{* *}$ & Pre $>$ Post & $5.68^{* *}$ & Pre $>$ Post \\
\hline Total density & - & & $4.26^{* *}$ & Pre $>$ Post \\
\hline $\mathrm{H}^{\prime}$ & $-2.93^{*}$ & Post $>$ Pre & $3.98^{* *}$ & Pre $>$ Post \\
\hline \multicolumn{5}{|l|}{ FFG } \\
\hline Scrapers & - & & $6.87^{* *}$ & Pre $>$ Post \\
\hline Shredders & $2.76^{*}$ & Pre $>$ Post & $2.83^{* *}$ & Pre $>$ Post \\
\hline Collector-filterers & - & & $2.98^{*}$ & Pre $>$ Post \\
\hline Predators & - & & $3.43^{* *}$ & Pre $>$ Post \\
\hline Algal piercers & - & & nd & \\
\hline
\end{tabular}

Dependent samples examining the effects of volcanic ashfall on species richness, total density, Shannon diversity index $\left(\mathrm{H}^{\prime}\right)$, and density of functional feeding groups on the two studied sites (Northwestern Patagonia Argentina). nd, variable non detected on the river. ${ }^{*} p<0.05$ and ${ }^{* *} p<0.005$. 
clearly displayed in seasonal comparison during spring (October) and summer (February) (Figure 3, Table 3).

At Chiquito Stream, the density of scrapers, shredders, collector-filterers, and predators significantly decreased after the eruption (Table 3). A strong reduction in scrapers' contribution at all seasons was evidenced for the first and second years when comparing consecutive years. The relative contribution of shredders increased in spring (October) on following years after the ashfall (Figure 3).

\section{Caddisfly trait ordination}

All traits and trait states employed in the ordination are detailed in Table 4; trait state assignment for each caddisfly species is shown in Table 5. PCA identified major patterns in biological traits, for the two studied streams. The first two axes explained $84.2 \%$ and $96 \%$ of the variance in trait data for Nant y Fall and Chiquito Streams, respectively (Figure 4b, d). In both PCA ordinations, traits were ordered along the first axis according to their sensitivity to ashfall (Figure $4 \mathrm{~b}$, d), with pre-eruption sampling dates located toward negative values, and post-eruption dates grouped toward the positive end (Figure 4a, c). Therefore, in both ordination models, PCA1 highlighted a disturbance gradient (Figure 4).

Accordingly, trait states sensitive to disturbance were well synchronized cycles, non-streamlined body shape, life-cycle longer than 10 months and the presence of gills for respiration (Figure $4 b, d$ ). Other features such as larvae with mineral or inorganic cases, sedentary/attached life forms, and a preference for erosional habitats were also, to a lesser extent, sensitive to sediment deposition. In contrast, trait states associated with the posteruption period were detritus feeding, filter-feeders, and poorly sclerotized larvae which were grouped toward the positive end of PCA1 (Figure 4b, d).

\section{Discussion}

According to predictions of the habitat templet model (Southwood 1977), the representation of biological traits are expected to reflect the functional relationships between biota and environmental characteristics (Townsend et al. 1997; Lamoroux et al. 2004; Dolédec et al. 2011). Our study suggests that changes in environmental conditions due to the volcanic eruption, an intense and noncyclical event, could favor those caddisfly species with trait profiles that allow them to tolerate heavy sediment deposition. In general, traits related with life history and morphological features are clearly the most responsive to sediment impairment (Vandewalle et al. 2010). Species with long (>10 months) and well-synchronized life cycles were severely affected. Species displaying short or poorly synchronized life cycles did not disappear after the episode; these attributes seem to be common at frequently disturbed systems including sedimentation and flooding episodes (Mellado Díaz et al. 2008).

Sedentary, non-streamlined, and gill respiration larvae, as well as those bearing mineral refugia were negatively affected by the successive ash remobilization and sedimentation, this is consistent with that reported by Townsend et al. (1997).
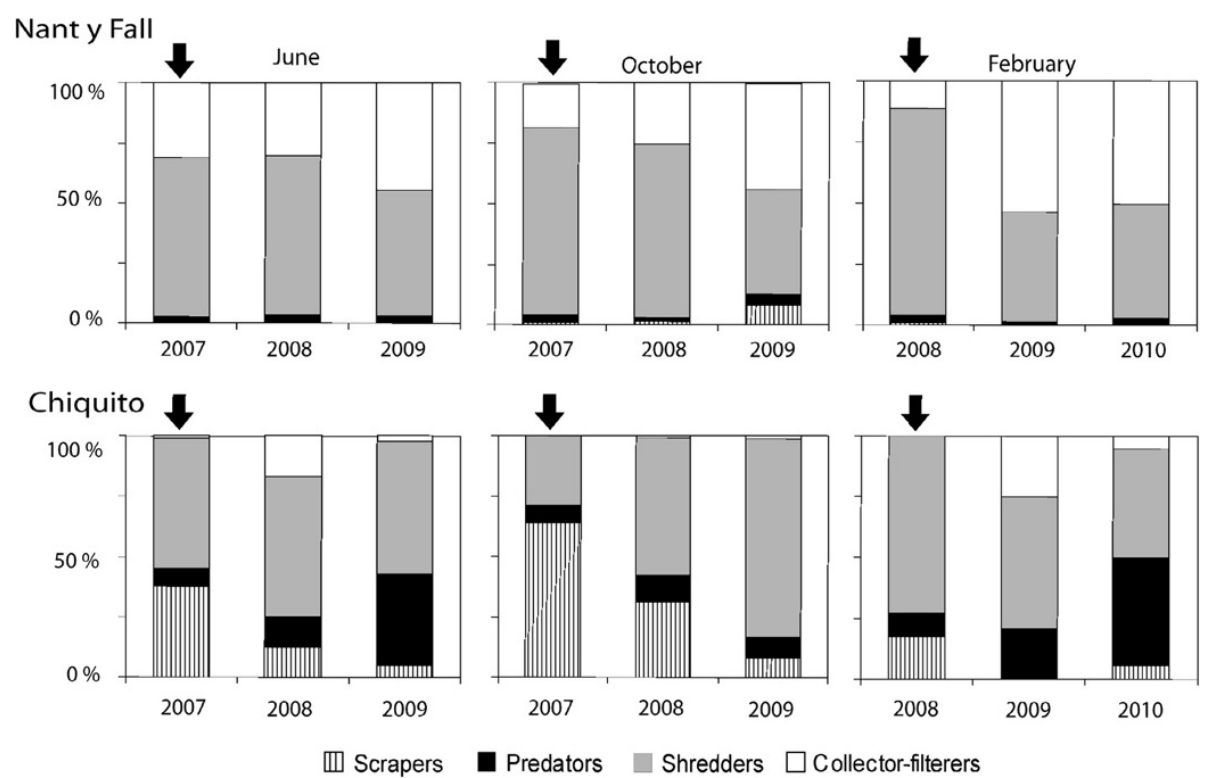

Figure 3 Relative abundance of the main functional feeding groups for Nant y Fall and Chiquito Streams (Patagonia, Argentina). Comparing three seasons (June: winter; October: spring, and February: summer) in consecutive years (2007 to 2009 ). Pre-eruption data in first column (marked with arrow) and post-eruption data in second and third column. 
Table 4 Description of the 11 traits (35 states) for all caddisfly species considered in this study

\begin{tabular}{lcc}
\hline Trait & Trait state (modality) & Code \\
\hline Life history & Short (<10 months) & LC1 \\
Life cycle & Long ( $>10$ months) & LC2 \\
& Poorly synchronized & Sy1 \\
Synchronicity & Well synchronized & Sy2 \\
Morphology & None (free ranging) & \\
Attachment & Some (sedentary sessile) & At1 \\
& None (soft body forms) & Ar1 \\
Armoring & Poor (heavily sclerotized) & Ar2 \\
& Good (mineral cased larvae) & Ar3 \\
Shape & Streamlined (fusiform) & Sh1 \\
& Not streamlined (round, or bluff) & Sh2 \\
Size & Small (<9 mm) & Si1 \\
& Medium (9-16 mm) & Si2 \\
& Large (>16 mm) & Si3 \\
Respiration & Tegument & Re1 \\
& Gills & Re2
\end{tabular}

Ecology

Rheophily

Depositional only

Depositional and erosional

Erosional only

Habitat preference

Food Boulder/cobble/pebble Gravel

Sand

Macrophytes

Organic detritus litter

Detritus $(<1 \mathrm{~mm})$

Plant detritus $(>1 \mathrm{~mm})$

Living macrophytes

Living microphytes

Living macroinvertebrates
Feeding habits

$\begin{array}{cc}\text { Deposit feeder } & \mathrm{FH} 1 \\ \text { Shredder } & \mathrm{FH} 2 \\ \text { Scraper } & \mathrm{FH} 3 \\ \text { Filter-feeder } & \mathrm{FH} 4 \\ \text { Piercer } & \mathrm{FH} 5 \\ \text { Predator } & \mathrm{FH} 6\end{array}$

The letter in each code refers to the trait and the number assigned to the trait state.

Traits hypothesized as resilient increased in frequency on post-eruption dates. Poorly sclerotized and free-living larvae appeared to be less sensitive to impairment; this may be related to increased mobility. Consistent with these observations, Buendia et al. (2013) found that mobile and streamlined forms were able to tolerate sedimentation by moving out of the impaired areas, while less mobile species were negatively affected.

Life history traits represent an important factor contributing to resilience following a disturbance (Wallace 1990). Species with shorter life cycles seem to be better colonizers than those having longer ones (Collier et al. 2002). Brand and Miserendino (2011a, 2012) showed that most of the dominant caddisfly species in the study area were univoltine, with relatively well-synchronized life cycles, a pattern that seems to be the most common for Patagonian Trichoptera. Our study suggests that species with highly synchronized life cycles and egg hatching coinciding with the ashfall period (e.g., Mastigoptila longicornuta, Scotiotrichia ocreata (Glossosomatidae); Brachysetodes quadrifidus (Leptoceridae); and Eosericostoma aequispina (Helicophidae) were those most strongly affected. These species showed an important decrease in density, probably due to the disturbance that took place during their larval recruitment and to a decrease in the quality of their main food supply (i.e., epilithon).

In line with a recent study (Miserendino et al. 2012), a clear distinction in Trichoptera communities between pre- and post-eruption sampling dates was observed, with a significantly decreased density and species richness at both streams. This also has been reported for other volcanically impaired streams (Anderson and Wisseman 1987; Anderson 1992; Dorava and Milner 1999; Collier et al. 2002). Moreover, significant changes in Trichoptera richness and density of some functional feeding groups were associated with the ashfall event. In this sense, a decrease in overall scrapers density, and absence of some scrapers species was detected, probably due to a reduction in food resources. During the study timeframe (22 months after the eruption) the scrapers Metrichia patagonica and Metrichia neotropicalis were completely eradicated from Chiquito site, while other species showed a strong decrease in density. The large amounts of sediment deposited in the streams could have diminished the quality of algal food supply in epilithic communities as demonstrated by Izagirre et al. (2009). This in turn could have a negative influence on the density of some invertebrate species (Graham 1990; Collier 2002).

Shredders were significantly less abundant in posteruption samples, suggesting that either habitat and/or leaf litter became unsuitable after the sedimentation process. Kreutzweiser et al. (2005) encountered similar effects on shredders at sites where sediment input from logging activities increased. They argue that this event may be derived from the physical interference of sediments on the species' feeding behavior or by reducing palatability of particulate organic matter as a consequence of a poor microbial colonization and conditioning. It has 
Table 5 Trait matrix for caddisfly taxa

\begin{tabular}{|c|c|c|c|c|c|c|c|c|c|c|c|}
\hline \multirow{3}{*}{ Glossosomatidae } & \multicolumn{2}{|c|}{ Life history } & \multicolumn{5}{|c|}{ Morphology } & \multicolumn{4}{|c|}{ Ecology } \\
\hline & \multirow[t]{2}{*}{ LC } & \multirow[t]{2}{*}{ Sy } & \multirow[t]{2}{*}{ At } & \multirow[t]{2}{*}{$\mathrm{Ar}$} & \multirow[t]{2}{*}{ Sh } & \multirow[t]{2}{*}{$\mathrm{Si}$} & \multirow[t]{2}{*}{$\operatorname{Re}$} & \multirow[t]{2}{*}{$\mathrm{Rh}$} & \multirow[t]{2}{*}{ HP } & \multirow[t]{2}{*}{ Fo } & \multirow[t]{2}{*}{$\mathrm{FH}$} \\
\hline & & & & & & & & & & & \\
\hline Scotiotrichia ocreata & 1 & 2 & 1 & 3 & 2 & 1 & 2 & 3 & 1 & 4 & 3 \\
\hline Mastigoptila longicornuta & 1 & 2 & 1 & 3 & 2 & 1 & 2 & 3 & 1 & 4 & 3 \\
\hline \multicolumn{12}{|l|}{ Helicophidae } \\
\hline Austrocentrus valgiformis & 2 & 2 & 1 & 3 & 2 & 1 & 2 & 3 & 1 & 4 & 3 \\
\hline Eosericostoma aequispina & 2 & 2 & 1 & 3 & 2 & 1 & 2 & 3 & 1 & 4 & 3 \\
\hline \multicolumn{12}{|l|}{ Hydrobiosidae } \\
\hline Atopsyche sp. & 2 & 1 & 1 & 1 & 2 & 2 & 2 & 3 & 1 & 6 & 6 \\
\hline Cailloma pumida & 2 & 1 & 1 & 1 & 2 & 2 & 2 & 3 & 1 & 6 & 6 \\
\hline Metachorema griseum & 2 & 1 & 1 & 1 & 2 & 2 & 2 & 3 & 1 & 6 & 6 \\
\hline Neoatopsyche brevispina & 2 & 1 & 1 & 1 & 2 & 2 & 2 & 3 & 1 & 6 & 6 \\
\hline Neoatopsyche unispina & 2 & 1 & 1 & 1 & 2 & 2 & 2 & 2 & 1 & 6 & 6 \\
\hline Neopsilochorema tricarinatum & 2 & 1 & 1 & 1 & 2 & 2 & 2 & 3 & 1 & 6 & 6 \\
\hline Rheochorema lobuliferum & 2 & 1 & 1 & 1 & 2 & 2 & 2 & 3 & 1 & 6 & 6 \\
\hline Rheochorema robustum & 2 & 1 & 1 & 1 & 2 & 2 & 2 & 3 & 1 & 6 & 6 \\
\hline Rheochorema tenuispinum & 2 & 1 & 1 & 1 & 2 & 2 & 2 & 3 & 1 & 6 & 6 \\
\hline \multicolumn{12}{|l|}{ Hydropsychidae } \\
\hline Smicridea annulicornis & 2 & 2 & 2 & 1 & 2 & 2 & 1 & 3 & 1 & 1 & 4 \\
\hline Smicridea frequens & 2 & 2 & 2 & 1 & 2 & 2 & 1 & 3 & 1 & 1 & 4 \\
\hline \multicolumn{12}{|l|}{ Hydroptilidae } \\
\hline Oxyethira bidentata & 1 & 2 & 2 & 2 & 1 & 1 & 2 & 2 & 4 & 3 & 5 \\
\hline Hydroptilidae sp. A & 1 & 2 & 2 & 2 & 1 & 1 & 2 & 2 & 2 & 4 & 3 \\
\hline Metrichia patagónica & 1 & 2 & 2 & 2 & 1 & 1 & 2 & 2 & 4 & 4 & 3 \\
\hline Metrichia neotropicalis & 1 & 2 & 2 & 2 & 1 & 1 & 2 & 2 & 4 & 4 & 3 \\
\hline \multicolumn{12}{|l|}{ Leptoceridae } \\
\hline Brachysetodes quadrifidus & 2 & 2 & 2 & 2 & 2 & 2 & 2 & 2 & 2 & 2 & 2 \\
\hline Hudsonema flaminii & 2 & 2 & 2 & 2 & 2 & 2 & 2 & 2 & 4 & 2 & 2 \\
\hline Triplectides sp. & 2 & 2 & 2 & 2 & 2 & 2 & 2 & 2 & 5 & 2 & 2 \\
\hline \multicolumn{12}{|l|}{ Limnephilidae } \\
\hline Austrocosmoecus hirsutus & 2 & 2 & 1 & 3 & 2 & 3 & 1 & 3 & 1 & 2 & 2 \\
\hline Monocosmoecus sp. & 2 & 2 & 1 & 3 & 2 & 3 & 1 & 2 & 1 & 2 & 2 \\
\hline Verger sp. & 2 & 2 & 1 & 3 & 2 & 3 & 1 & 2 & 3 & 2 & 2 \\
\hline \multicolumn{12}{|l|}{ Philorheithridae } \\
\hline Psilopsyche molinai & 2 & 2 & 1 & 3 & 2 & 3 & 2 & 3 & 1 & 6 & 6 \\
\hline Polycentropodidae & & & & & & & & & & & \\
\hline Polycentropus sp. & 2 & 2 & 1 & 1 & 2 & 3 & 2 & 1 & 2 & 6 & 6 \\
\hline Sericostomatidae & & & & & & & & & & & \\
\hline Myotrichia murina & 2 & 1 & 2 & 3 & 2 & 2 & 2 & 1 & 5 & 2 & 2 \\
\hline Parasericostoma cristatum & 2 & 1 & 2 & 3 & 2 & 2 & 2 & 3 & 1 & 2 & 2 \\
\hline Parasericostoma ovale & 2 & 1 & 2 & 3 & 2 & 2 & 2 & 3 & 1 & 2 & 2 \\
\hline
\end{tabular}

Trait abbreviations and descriptions are provided in Table 4. 

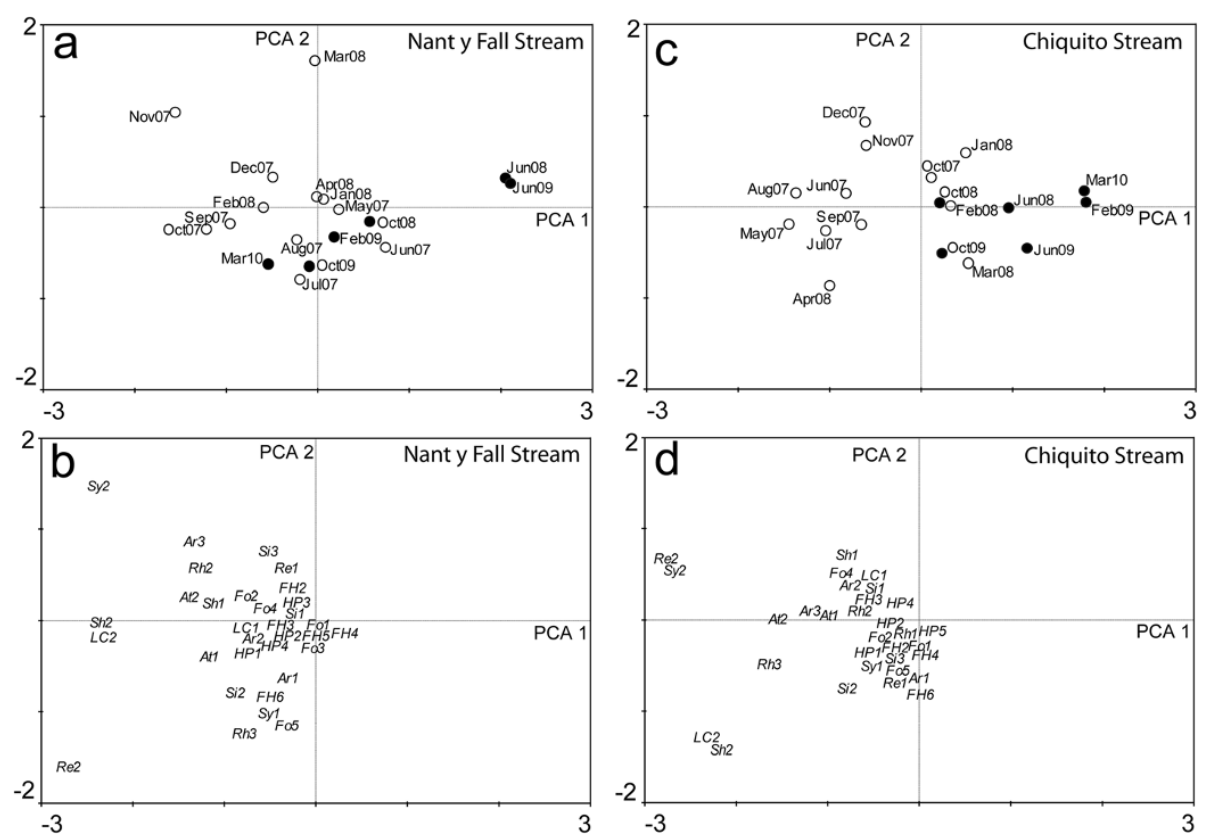

Figure 4 PCA ordination. Shows the position of sampling dates (May 2007-March 2010) for (a) Nant y Fall and (c) Chiquito streams; and trait composition at (b) Nant y Fall and (d) Chiquito Streams (Patagonia, Argentina), for the same coordinates. Open circles correspond to preeruption sampling dates, and filled circles indicate post-eruption sampling dates. Codes for trait states are described in Table 4.

been suggested that filtering devices, such as the nets built by the Hydropsychidae species, may be obstructed by inorganic suspended sediments transported by the water column (Wood and Armitage 1997; Wantzen 2006; Buendia et al. 2013). Nevertheless, species at Nant y Fall Stream (i.e., Smicridea annulicornis and S. frequens, Hydropsychidae) appeared to be unaffected by ashfall, since pre- and post-eruption density values were nearly the same. Moreover, their recruitment period occurred mostly in February (Brand and Miserendino 2012), attaining a mixed size structure (larval instars 3 and 4 at the same time) at the time of the ashfall. Other features that probably contributed to the survival of these species were their active behavior, their ability to move and clean the net used for filtering, or their capacity to abandon an old net and build a new one. According to Brand and Miserendino (2011a, 2012) predator species (N. brevispina and Neopsilochorema tricarinatum, Hydrobiosidae), have poorly synchronized life cycles, with an extended recruitment and co-occurrence of many size classes during several months of the year. Volcanic ash deposition had a minor effect on them, as shown in the present study. Traits displayed by the two species (e.g., poorly synchronized life cycles, high mobility, no mineral case, no gill respiration system) as well as in other hydrobiosids, could result in resilience to disturbances such as high inputs of fine sediment.

The overall success of diverse benthic macroinvertebrate communities is strongly dependent on their physical integrity of their environment (Karr et al. 1986). Since many macroinvertebrates require specific substrates for oviposition and the completion of other life cycle stages (Merritt and Cummins 1996), sedimentation can ultimately result in the local extinction of certain species (Waters 1995). Sediment deposition affects macroinvertebrate communities by reducing the number of suitable habitats (Chutter 1968), decreasing substrate stability which in turn increases drift rates (Suren and Jowett 2001), reducing food resources and food quality (Broekhuizen et al. 2011), or by affecting aquatic respiration due to deposition of silt on respiratory structures (Lemly 1982). In all cases, the timing of the ashfall and the population features such as size structure, at that moment seemed to play a determining role on the ultimate effect on species.

Nearly 2 years after the first Chaitén ashfall, the Trichoptera community was not yet fully recovered at Chiquito Stream. Nant y Fall Stream, however, showed a lower impact than Chiquito and by March 2010 caddisfly richness and density reached similar values to those before the ashfall. At Chiquito Stream, the Trichoptera community showed no signs of recovery at the end of the study period, with some species being absent from the samples and density values of other species consistently lower than pre-eruption ones. Similar results were documented by Lallement et al. (2014), for other Patagonian streams affected by heavy ashfall produced by Puyehue-Cordón Caulle eruption (2011). After the 
Chaitén eruption, Miserendino et al. (2012) found that the effects were more dramatic in small rivers than in larger ones, which are characterized by a larger discharge. Anderson (1992) also observed that the increases in density, biomass, and diversity after a volcanic episode (Mt. Saint Helen) were related with the stabilization of stream bed. Five years after the Redoubt eruption, Dorava and Milner (1999) documented a recovery in the macroinvertebrate community, with unaffected upstream sites acting as sources for drifting organisms toward disturbed downstream areas.

While the presence of an epicenter or source of organisms for recolonization is vital, the survival chances of larvae in the impacted environment are related to how ashfall affected the provision of food, the composition of suitable substrates, and the amount of suspended solids. These factors would affect the colonization and reestablishment of the community structure to its reference values, within a particular habitat (Anderson and Wisseman 1987; Wallace 1990; Lallement et al. 2014). In the case of Chaitén ashfall, it is likely that periodic bankside and upstream sediment inputs due to wind and rainfall could act as a bottleneck to successful recolonization, delaying the reestablishment of original conditions and therefore preventing the caddisfly community from recovering.

\section{Conclusions}

Our study demonstrates that volcanic sedimentation causes high mortality on Trichoptera populations and has detectable ecological effects. The community recovery and successful reestablishment of original community values depend on the return to the suitable conditions of the studied streams. Moreover, certain traits such as poorly synchronized life cycle, filter feeder habits, tegumentary respiration, and good armoring (i.e., mineral case builders) were proved to be the most resilient to this kind of disturbance.

\section{Competing interests}

The authors declare that they have no competing interests.

\section{Authors' contributions}

CB participated in the design of the study; carried out the field work and sample processing; and drafted the manuscript. MLM participated in the design of the study and field work, collaborated with the statistical analysis, and helped to draft the manuscript. Both authors read and approved the final manuscript.

\footnotetext{
Acknowledgements

This paper was partially supported by CONICET (PIP 11220080101907). This is scientific contribution No. 96 from LIESA. The authors would like to thank

Dr. Luis Epele, Dr. Miguel Archangelsky, Dr. Cecilia Di Prinzio, and Dr. Ricardo Casaux for the fieldtrip assistance, and Dr. Gabriel M. Martin for the comments. We also thank the two anonymous reviewers for valuable comments that greatly improved the manuscript.
}

Received: 6 May 2014 Accepted: 10 September 2014

Published online: 17 December 2014

\section{References}

Anderson NH (1992) Influence of disturbance on insect communities in Pacific Northwest streams. Hydrobiologia 248:79-92

Anderson NH, Wisseman RW (1987) Recovery of the Trichoptera fauna near Mt St Helens five years after eruption. In: Bournaud M, Tachet $\mathrm{H}$ (eds) Proceedings of the 5th International Symposium on Trichoptera. Dr. W. Junk Publishers, Dordrecht/Boston/Lancaster, pp 367-373

Angrisano EB (1997) Contribution to the knowledge of the larvae of Hydrobiosidae. I. Neopsilochorema tricarinatum and Australochorema rectispinum. In: Otto C (ed) Proceedings of the 7th International Symposium on Trichoptera. Blackuys Publishers, Netherlands, pp 15-17

Angrisano EB, Sganga JV (2009) Trichoptera. In: Domínguez E, Fernández HR (eds) Macroinvertebrados bentónicos sudamericanos. Fundación Miguel Lillo, Tucumán, Argentina

Annen C, Wagner JJ (2003) The impact of volcanic eruptions during the 1990's. Nat Hazards 4:169-175

Antos JA, Zobel DB (2005) Plant responses in forests of the tephra-fall zone. In: Dale VH, Swanson FJ, Crisafulli CM (eds) Ecological responses to the 1980 eruption of Mount St. Helens. Springer, New York, pp 47-58

APHA (1999) Standard methods for the examination of water and wastewate. American Public Health Association, Hanover, MD

Borchardt D, Statzner B (1990) Ecological impact of urban stormwater runoff studied in experimental flumes: population loss by drift and availability of refugial space. Aquat Sci 52:299-314

Brand C, Miserendino ML (2011a) Life history strategies and production of caddisflies in a perennial headwater stream in Patagonia. Hydrobiologia 673(1):137-151. doi:10.1007/s10750-011-0768-3

Brand C, Miserendino ML (2011b) Characterizing Trichoptera trophic structure in rivers under contrasting land use in Patagonia, Argentina. In: Majecka K, Majecki J, Morse J (eds) Proceedings of the 13th International Symposium on Trichoptera. Magnolia Press, New Zealand, Zoosymposia, pp 29-40

Brand C, Miserendino ML (2012) Life cycle phenology, secondary production, and trophic guilds of caddisfly species in a lake-outlet stream of Patagonia. Limnologica 42(2):108-117. doi:10.1016/j.limno.2011.09.004

Brand C, Miserendino ML, Epele LB (2012) Spatial and temporal pattern of caddisfly distribution at a mesohabitat scale in two Patagonian mountain streams subjected to pastoral use. Int Rev Hydrobiol 97(2):83-99. doi:10.1002/iroh.201111368

Broekhuizen N, Parkyn S, Miller D (2011) Fine sediment effects on feeding and growth in the invertebrate grazers Potamopyrgus antipodarum (Gastropoda, Hydrobiidae) and Deleatidium sp. (Ephemeroptera, Leptophlebiidae). Hydrobiologia 457:125-132

Buendia C, Gibbins CN, Vericat D, Batalla RJ, Douglas A (2013) Detecting the structural and functional impacts of fine sediment on stream invertebrates. Ecol Ind 25:184-196. doi:10.1016/j.ecolind.2012.09.027

Chutter FM (1968) The effects of silt and sand on the invertebrate fauna of streams and rivers. Hydrobiologia 34:57-76

Collier KJ (1995) Environmental factors affecting the taxonomic composition of aquatic macro-invertebrate communities in lowland waterways of Northland New Zealand. New Zeal J Mar Freshwat Res 29:453-465

Collier KJ (2002) Effects of flow regulation and sediment flushing on instream habitat and benthic invertebrates in a New Zealand river influenced by a volcanic eruption. River Res Applic 18:213-226

Collier KJ, Parkyn SM, Quinn JM, Scarsbrook MR (2002) Bouncing back: how fast can stream invertebrates recolonise? Water Atmosph 10(2):9-11

Coronato FR, Del Valle HF (1988) Caracterización hídrica de las cuencas hidrográficas de la provincia del Chubut. Cenpat-Conicet, Puerto Madryn, Chubut, Argentina

Del Moral R, Grishin SY (1999) Volcanic disturbances and ecosystem recovery. In: Walker LR (ed) Ecosystems of Disturbed Ground. Ecosystems of the World 16. Vol. 2, Elsevier, New York, USA, pp 137-155

Doeg TJ, Milledge GA (1991) Effects of experimentally increasing concentrations of suspended sediment on macroinvertebrate drift. Aust J Mar Freshwat Res 42:519-526

Dolédec S, Phillips N, Townsend C (2011) Invertebrate community responses to land use at a broad spatial scale: trait and taxonomic measures compared in New Zealand rivers. Freshwat Biol 56(8):1670-1688. doi:10.1111/j.1365-2427.2011.02597.x

Dorava JM, Milner AM (1999) Effects of recent volcanic eruptions on aquatic habitat in the Drift River, Alaska, USA: implications at other cook inlet region volcanoes. Environ Manag 23(2):217-230 
Feio MJ, Dolédec S (2012) Integration of invertebrate traits into predictive models for indirect assessment of stream functional integrity: a case study in Portugal. Ecol Ind 15:236-247

Gordon ND, McMahon TA, Finlayson BL, Gippel CJ, Nathan RJ (2004) Stream hydrology: an introduction for ecologists. John Wiley \& Sons, Ltd., Sussex, England

Graham AA (1990) Siltation of stone-surface periphyton in rivers by clay sized particles from low concentrations in suspension. Hydrobiologia 199:107-115

Inbar M, Ostera HA, Parica CA, Remesal MB, Salani FM (1995) Environmental assessment of 1991 Hudson volcano eruption ashfall effects on southern Patagonia region, Argentina. Env Geol 25:119

Izagirre O, Serra A, Guasch H, Elosegi A (2009) Effects of sediment deposition on periphytic biomass, photosynthetic activity and algal community structure. Sci Total Environ 407(21):5694-5700

Jobbágy EG, Paruelo JM, León JC (1995) Estimación de la precipitación y de su variabilidad interanual a partir de información geográfica en el NW de Patagonia, Argentina. Ecol Austr 5:47-53

Jones MT, Gislason SR (2008) Rapid releases of metal salts and nutrients following the deposition of volcanic ash into aqueous environments. Geochim Cosmochim Acta 72:3661

Karr JR, Fausch JD, Yant PR, Schlosser IL (1986) Assessing biological integrity in running waters: a method and its rationale. Illinois Natural History Survey Special Publication 5, Champaign, IL, USA

Kreutzweiser DP, Capell SS, Good KP (2005) Effects of fine sediment inputs from a logging road on stream insect communities: a large-scale experimental approach in a Canadian headwater stream. Aquat Ecol 39(1):55-66. doi:10.1007/s10452-004-5066-y

Lallement ME, Juárez SM, Macchi PJ, Vigliano PH (2014) Puyehue Cordón-Caulle: post-eruption analysis of changes in stream benthic fauna of Patagonia. Ecol Austr 24:64-74

Lamoroux N, Dolédec S, Gayraud S (2004) Biological traits of stream macroinvertebrate communities: effect of microhabitat, reach and basin filters. J N Am Benthol Soc 23:449-449

Larsen SE, Ormerod SJ (2010) Combined effects of habitat modification on trait composition and species nestedness in river invertebrates. River Res Applic 143:2638-2646

Lemly AD (1982) Modification of benthic insect communities in polluted streams: combined effects of sedimentation and nutrient enrichment. Hydrobiologia $87: 229-245$

León R, Bran D, Collantes M, Paruelo JM, Soriano A (1998) Grandes unidades de vegetación de la Patagonia extra andina. Ecol Austr 8:125-144

Martin RS, Watt SFL, Pyle DM, Mather TA, Matthews NE, Georg RB (2009) Environmental effects of ashfall in Argentina from the 2008 Chaitén volcanic eruption. J Volcanol Geotherm Res 184:462-472

McDowall RM (1996) Volcanism and freshwater fish biogeography in the northeastern North Island of New Zealand. J Biogeogr 23:139-148

Mellado Díaz A, Suárez Alonso ML, Vidal-Abarca Gutiérrez MR (2008) Biological traits of stream macroinvertebrates from a semi-arid catchment: patterns along complex environmental gradients. Freshwat Biol 53:1-21. doi:10.1111/ j.1365-2427.2007.01854.x

Merritt RM, Cummins KW (1996) An introduction to the aquatic insects of North America, 3rd edn. Kendall /Hunt Publishing Company, Dubuque, lowa

Merritt RW, Cummins KW, Berg MP (2008) An introduction to the aquatic insects of North America, 4th edn. Kendall/Hunt Publishing Company, Dubuque, lowa

Miserendino ML, Masi Cl (2010) The effects of land use on environmental features and functional organization of macroinvertebrate communities in Patagonian low order streams. Ecol Ind 10(2):311-319. doi:10.1016/ j.ecolind.2009.06.008

Miserendino ML, Archangelsky M, Brand C, Epele LB (2012) Environmental changes and macroinvertebrate responses in Patagonian streams (Argentina) to ashfall from the Chaitén Volcano (May 2008). Sci Total Environ 424:202-212. doi:10.1016/j.scitotenv.2012.02.054

Nillni A, Bitschene PR (1995) Sedimentología y procesos de sedimentación de la tefra caída de la erupción del volcán Hudson en agosto de 1991. In: Bitschene PR, Mendía J (eds) The august eruption of the Hudson Volcano (Patagonian Andes): a thousand days after. Universidad Nacional de la Patagonia San Juan Bosco, Servicio Nacional de Geología, Comodoro Rivadavia, Argentina, pp 116-134

Óskarsson N (1980) The interaction between volcanic gases and tephra: fluorine adhering to tephra of the 1970 Hekla eruption. J Volcanol Geotherm Res 8:251-266
Ovdas S (2008) Erupción del volcán Chaitén Informes técnicos (mayo). Servicio Nacional de Geología y. Minería, Gobierno de Chile

Pallister JS, Major JJ, Pierson TS, Hoblitt RP, Lowernstern JB, Eichelberger JC (2010) Interdisciplinary studies of eruption at Chaitén Volcano, Chile. Eos Transactions AGU 91:19

Paruelo JM, Beltrán A, Jobbágy E, Sala OE, Golluscio RA (1998) The climate of Patagonia : general patterns and controls on biotic processes. Ecol Austr 8:85-101

Paul MJ, Meyer JL (2001) Streams in the urban landscape. Ann Rev Ecol System 32:333-365

Pedersen ER, Perkins MA (1986) The use of benthic macroinvertebrate data for evaluating impacts of urban runoff. Hydrobiologia 139:13-22

Poff NL, Olden JD, Vieira NKM, Finn DS, Simmons MP, Kondratieff BC (2006) Functional trait niches of North American lotic insects: traits-based ecological applications in light of phylogenetic relationships. J N Am Benthol Soc 25(4):730-755

Ruggieri F, Fernández-Turiel JL, Saavedra J, Gimeno D, Polanco E, Naranjo JA (2011) Environmental geochemistry of recent volcanic ashes from the Southern Andes. Environ Chem 8(3):236. doi:10.1071/EN10097

Sganga JV, Fontanarrosa MS (2006) Contribution to the knowledge of the preimaginal stages of the genus Smicridea McLachlan in South America (Trichoptera: Hydropsychidae: Smicrideinae). Zootaxa 1258:1-15

Sokal RR, Rohlf FJ (1995) Biometry, 3rd edn. W.H. Freeman and Company, New York, USA

Southwood TRE (1977) Habitat, the templet for ecological strategies? J Anim Ecol 46(2):336-365

Statzner B, Bêche $L$ (2010) Can biological invertebrate traits resolve effects of multiple stressors on running water ecosystems? Freshwat Biol 55:80-119. doi:10.1111/j.1365-2427.2009.02369.x

Statzner B, Doledec S, Hugueny B (2004) Biological trait composition of European stream invertebrate assemblages: assessing the effects of various trait filter types. Ecogeography 27:470-488

Suren AM, Jowett IG (2001) Effects of deposited sediment on macroinvertebrate drift: an experimental study. New Zeal J Mar Fresh Res 35:725-738

Ter Braak CJF, Smilauer P (1998) CANOCO reference manual and user's guide to Canoco for Windows. Software for Canonical Community Ordination (Version 4), Microcomputer power, Ithaca, N.Y

Townsend CR, Scarsbrook MR, Dolédec S (1997) The intermediate disturbance hypothesis, refugia, and biodiversity in streams. Limnol Oceanogr 42(5):938-949

Vandewalle M, Bello F, Berg MP, Bolger T, Dolédec S, Dubs F, Feld CK, Harrington R, Harrison P, Lavorel S, Martins P, Da Silva M, Moretti JN, Santos P, Sattler T, Sousa JP, Sykes MT, Vanbergen AJ, Woodcock BA (2010) Functional traits as indicators of biodiversity response to land use changes across ecosystems and organisms. Biodivers Conserv 19(10):2921-2947. doi:10.1007/s10531-010-9798-9

Wallace JB (1990) Recovery of lotic macroinvertebrate communities from disturbance. Environ Manage 14(5):605-620

Wantzen KM (1998) Siltation effects on benthic communities in first order streams in Mato Grosso. Verh Int Verein Limnologie 26:1155-1159

Wantzen KM (2006) Physical pollution: effects of gully erosion on benthic invertebrates in a tropical clear-water stream. Aquat Conserv 16:733-749. doi:10.1002/aqc

Ward JV (1992) Aquatic insect ecology. Wiley, New York-London

Waters TF (1995) Sediment in streams: sources, biological effects, and control. American Fisheries Society, Bethesda, USA

Watt SFL, Pyle DM, Mather TA, Martin RS, Matthews NE (2009) Fallout and distribution of volcanic ash over Argentina following May 2008 explosive eruption of Chaitén. Chile. J, Geophys Res, p 114

Witham CS, Oppenheimer C, Horwell CJ (2005) Volcanic ash-leachates: a review and recommendations for sampling methods. J Volcanol Geotherm Res 141:299-326

Wood PJ, Armitage PD (1997) Biological effects of fine sediment in the lotic environment. Environ Manage 21(2):203-217

doi:10.1186/s40555-014-0072-9

Cite this article as: Brand and Miserendino: Biological traits and community patterns of Trichoptera at two Patagonian headwater streams affected by volcanic ash deposition. Zoological Studies 2014 53:72 